by the scientific physician, and is deservedly punished by intrigues on the part of the indifferentist, who has nothing better to do. If consulting staffs be, as in the New York city hospitals, mainly composed of dilettante and medical politicians, they are useless ; if, as was the case at one time in the Cook County Hospital, they interfere with the discipline of the hospital, they are pernicious: neither a louse nor a hospital divided against itself can stand. The remarks on gynæcological treatment are not as just as might be expected from the general tenor of $\mathrm{Dr}$. Ayres' article. With the results of the rash gynæcological experiments in the New York city hospitals in remembrance, the "culpable" (laisser aller) policy of the superintendents has at least partial justification. The remarks on restraint are not judicious ; every thing is liable to abuse. To abolish a thing because of its liability to abuse is an argument justifying the disuse of medical treatment of insanity entirely. The means of prevention of cruelty proposed by Dr. Ayres are in active operation in every well-conducted hospital for the insane in the United States. This paper adds little to the practical resources of psychiatry. It shows very clearly, as did certain recent investigations in Kentucky, that the reform needed is not a reform of a system but of individuals. The transactions are well issued and well bound.

\title{
J. G. KIERNAN.
}

\section{Report of Investigation of the Central Kentucky Lu-} natic Asylum, Louisville, Ky. Gilbert \& Mallory Publishing Co., $\mathbf{1 8 8 3}$.

This pamphlet seems to bring us back to the time when Bethlehem Hospital for the Insane was a slaughter-house, it being run entirely by the attendants; and to the days in the New York City Asylum for the Insane when the supervisor was more afraid of the attendants than he was of the patients. Miss Chevallier has given, very charitably, Dr. GaLE credit for honesty in his intentions; but, even assuming that he is honest in his intentions, he is an unfit person for the position of superintendent of a hospital for the insane. $\mathrm{He}$ is, to speak plainly, either mendacious or ignorant about the practices of his brother superintendents, and if, to be charitable, he be ignorant of these, how ignorant must he be of psychiatry elsewhere. It appears from this pamphlet (p. 76), that attendants duck patients at their option and without physicians being present, or (p. 79) under the direction of the supervisor only; that (p. 83) attendants choke patients. 
Dr. Gale stated that in every hospital for the insane in the United States ducking is used as a punishment. When this statement was made in the Americal Fournal of Insanity, Dr. Hurd, of the Michigan Hospital for the Insane, at Pontiac, indignantly denied that such was the case at the institution under his charge. No such punishment is in use to the writer's knowledge in a single State hospital for the insane in the United States, other than that of Dr. Gale. To be sure the writer must confess that Dr. Wickes Washburn testified to the New York Senate Committee, that when Assistant Superintendent of the New York City Asylum for the Insane he ordered a patient to be ducked with his clothes on, but even that was done only by a physician. The present writer believes, like Krafft-Ebing, that the douche as a therapentic measure is useful in certain cases, but like all therapeutic measures should be employed only under the directions of a physician. This is also the opinion of Dr. C. H. Hughes, who says, Alienist and Neurologist, 1883: "The practice of ducking a patient for punishment is never justifiable, and if ever thought proper as a calmative of excitement it should never be relegated to any other person than a medical officer willing to take the responsibility for consequences." These are the words of one held in high esteem among superintendents of hospitals for the insane, who views the subject from the stand-point of a medical superintendent for the insane. With this preface a few citations may be made (p. go). Miss Kate Monroe on the stand :

"Q. Those patients that were ducked by you, what were they ducked for?

"A. General meanness.

"Q. Those that you ducked, did you do it by consent of the doctors?

"A. We got permission of Mrs. Riley (the matron).

Fanny Davis (p. 94). "Q. Was this ducking done by the instructions of the superintendent?

"A. Yes, sir. He told us when we could not control them in another way to give them a bath.

Bad Paul on the stand (p. 7r). "Q. Do you attendants give chloral without permission of the superintendent?

A. "It used to be the rule here, but it is not now.

Dr. R. H. Gale on the stand (p. 2o). "Q. You say that in ducking, the real object was to purge the patient's system, and that it was given as a dose of medicine? 
"A. I say that was part of the treatment, and sometimes it was resorted to as a punishment for the refractory.

"Q. How is this treatment regarded in other institutions ?

"A. That question has been discussed between medical superintendents publicly and privately. I cannot give any reference to any publications at this time, but it has been frequently discussed at the meetings of the superintendents.

"Q. Have you attended these meetings?

"Yes; I have attended them ever since I have been in charge of the institution, and I have yet to meet the first man who disagreed with me in my ideas on that subject. I learn from attendants here who have worked in other institutions that it is the practice, but you can learn that from themselves."

With these citations the subject can be left to the judgment of the reader, but the writer hopes that such a condition of things as has been shown to exist in the Central Kentucky Lunatic Asylum may not be paralleled in any other institution.

J. G. KIERNAN.

\section{La Folie Universelle et la Science Mentale. Par Ivan} Golovine. Paris : H. Lesoudier, I881.

There remains among a certain class of the insane seemingly otherwise recovered, an. irritability which amounts almost to a logical perversion. To the class of individuals so afflicted belongs, to all appearance, the author of these pamphlets, and on careful perusal of them a pretty accurate diagnosis of the author's mental condition might be made. One of these pamphlets is headed "Pathologiæ Psychique." In it are to be found statements like this : "When any one is stupid, says M. Rochefort, they remain so for a long time, and the asylum physicians are dry fruits, for the most part incapable of earning their bread in the city. Such is, however, the power of their association, that men in high places refuse to serve for fear of putting themselves in the hands of the alienist physicians." ... "This sequestromania will only end when the alienists are obliged to pay heavy damages for false imprisonment." In another, headed "La Monomanie de Persécution," it is stated that "the Estoret crime has made everybody indignant, but when it is learned what occurs in the asylums which Europe envies France, the world will recoil with horror and fright." It may also be said that the author is far from coherent in his ideas. With such pamphlets filling the book-stands, it is scarcely astonishing that Dr. Foville should vent his indignation in some manner, and this he 